\title{
Štefánik ako dobrodružstvo histórie
}

\author{
Dagmar Inštitorisová (Nitra)
}

Peter Macho: Milan Rastislav Štefánik ako symbol. Bratislava: Veda, 2019. 287 s. ISBN 978-80-224-1785-3.

Monografia slovenského historika Petra Macha Milan Rastislav Štefánik ako symbol vyšla v roku 2019, ktorý bol na Slovensku Rokom Milana Rastislava Štefánika. V rámci neho sa konal rad vedeckých a odborných podujatí venovaných jeho osobnosti, ako napríklad medzinárodná konferencia Milan Rastislav Štefánik MUŽ SLNKA, ktorú v apríli 2019 zorganizovalo viacero subjektov - Slovenská ústredná hvezdáreň Hurbanovo, Spoločnost’ M. R. Štefánika so sídlom v Brezovej pod Bradlom a Mesto Pieštany. Jej výsledkom bol zborník, v ktorom sa na osobnost' Štefánika pozrelo vel'mi široké spektrum odborníkov - od astronómov, kozmonautov, politikov, historikov, historikov umenia až po muzeológov. Tomuto roku však dominovali hlavne monografické texty, publikované doma a v zahraničí. Za mimoriadny úspech je možné považovat hlavne vydanie monografie s názvom Milan Rastislav Štefánik od historika Michala Kšiňana nielen v slovenskom jazyku, ale v samostatných vydaniach v nemeckom, anglickom a francúzskom jazyku, hlavne vydanie jeho L'homme qui parlait avec les étoiles. Milan Rastislav Štefánik, héros franco-slovaque de la Grande Guerre v parížskom Eur'Orbem. Počinom je aj vydanie monografie Slavomíra Michálka v anglickom jazyku pod názvom Milan Rastislav Štefánik and those who followed him, ktoré vyšlo v slovenskej VEDE a nemeckom vydavatel'stve Peter Lang. O Štefánikovej osobnosti sú vd’aka tomu dostupné informácie pre bádatelov i jeho obdivovatel'ov v troch svetových jazykoch.

Obálku Machovej monografie trochu provokatívne, ale zároveň aj symbolicky a v súlade s obsahovým zameraním textu, tvorí Štefánikov portrét od ilustrátora Jozefa Giertliho Danglára. Ako píše v tiráži sám P. Macho: „[...] obsahuje symbolické atribúty a odkazy spojenés M. R. Štefánikom (generálsku čiapku, jeho heslo vytetované na ramene, vojenskú známku s č́slom planétky pomenovanej po Štefániko- vi atd.)“ (s. 2). Provokatívnost’ obálky je spojená s textom nezvyčajnejším pohladom Petra Macha na danú osobnost'. Ako historik sa nezameriava na skúmanie Štefánikovho života, ale mapuje spôsob jeho zobrazovania od jeho skonu po nedávnu súčasnosṫ v rôznych súvislostiach. Tie sú tematizované $\mathrm{v}$ šiestich kapitolách, v ktorých sleduje jednak vel'mi odlišné až kontroverzné vnímanie tejto osobnosti v období prvej Československej republiky, vojnového Slovenského štátu, v rokoch od skončenia druhej svetovej vojny do roku 1948, v čase socializmu a v menšej miere aj v súčasnosti. Prvá kapitola má názov Ako sa vedec s dobrodružným životom stal národným hrdinom, druhá Neobyčajná história Štefánikovej pozostalosti, tretia Posmrtný kult M. R. Štefánika medzi ideológiou a umenim, štvrtá Štefánik vo verejnom priestore slovenských miest, piata Slovanstvo a Štefánik ako symbol v kontexte dobových medzištátnych vztahov a posledná Štefánik a Bradlo $v$ kontexte politiky, ideológie, identity a festivitnej kultúry - 1938-1939 a 1968-1969. Klúčom k takémuto neštandardnému uchopeniu Štefánikovej osobnosti, k sledovaniu spôsobov a foriem prisvojovania si jeho osobnosti až pozmeňovania a prekrúcania historických faktov a ich významu je pre Macha proces spoločensko-politickej a náboženskej mýtizácie udalostí a života nielen významných osobností. Je tesne spätá s tradovanou historickou pamätou šírenou ústnym podaním a s tým súvisiacou potrebnou či presnejšie nevyhnutným vytváraním obrazu národného hrdinu alebo antického héroa, či národného svätca - mučeníka a spasitela. V prípade Štefánika, jeho obraz ako národného hrdinu autor nespája iba so zásluhami o vznik prvého spoločného - samostatného - štátu Čechov a Slovákov, ale so stáročnou snahou Slovákov i Čechov o osamostatnenie, o vytvorenie štátu(ov), ktorý by bol nezávislý na Rakúsko-Uhorskej monarchii či Nemeckej rísi. V prípade pretvárania jeho obrazu 
na národného mučeníka upozorňuje na snahu katolíckej cirkvi využit jeho osobnost' na upevňovanie autonomistických politických snáh, v rámci ktorých sa mali Slováci odpútat od Čechov i tvrdením, že zavraždili Štefánika (s. 80 a i.). Štefánik sa spolu s Andrejom Hlinkom v určitých obdobiach stával až „svätcom“, a to aj napriek jeho evanjelickému vierovyznaniu a prísnej luteránskej výchove vzhladom na to, že jeho otec Pavol Štefánik bol evanjelickým kňazom. Ako kuriozitu Macho spomína aj príklady z výtvarného umenia, kedy sa síce ojedinele, ale predsa len vyskytli aj obrazy Štefánika so svätožiarou či prežehnávajúceho sa (s. 78). V rámci snáh o zludovenie jeho osobnosti sa v tomto období postupne menil aj obraz jeho matky Albertíny, ktorá sa stávala matkou mučeníka, prezentovala sa ako bolestná a strádajúca, podobne ako to bolo u Panny Márie (s. 81). V období Slovenského štátu však už privel'mi mrazivo pôsobí citát z prejavu Alexandra Macha v roku 1941 v Rajci, v rámci ktorého označil Štefánika za toho, ktorý by nielenže kráčal „za Adolfom Hitlerom, áno, bol by slovenským Hitlerom“ (s. 203). Nielenže sa v tomto období niektorými politikmi vedome začala popierat jeho účast na boji proti Nemecku na strane francúzskej armády, ale nacistické krídlo Hlinkovej slovenskej ludovej strany z neho vyfabrikovalo „vzorového stúpenca fašizmu č nacizmu“ (s. 203). V krátkom povojnovom období - do roku 1948 - sa P. Macho, samozrejme, venoval aj znovu oživeniu rôznych typov osláv na počest̉ tejto osobnosti a v období socializmu jeho zamlčovaniu a vymazávaniu z historickej pamäte Slovákov i Čechov. Otvorene píše aj o velkých problémoch pri dedičskom konaní, predlžovaní odkúpenia pozostalosti M. R. Štefánika od rodiny, jeho zadÍženosti už počas života, pretože vel'kú čast̉ svojich výskumných ciest si musel financo- vat' z vlastných prostriedkov, o tahaniciach okolo vzniku jeho múzea na Slovensku, ktoré vzniklo nakoniec až v roku $1990 \mathrm{v}$ jeho rodnom dome v Košariskách, píše o príčinách nesúhlasu evanjelickej cirkvi s mnohými politickými snahami predstavitelov katolíckej cirkvi v súvislosti s rôznymi reinterpretáciami Štefánikovho života a jeho politicko-spoločenských snáh, o nedobrovolnom putovaní jeho sôch takmer po celom Slovensku na nové miesta a spät na pôvodné, ich rozbíjaní a ničení v dobe socializmu atd'.

Na monografii je zaujímavá ešte jedna vec - štýl písania. Vd’aka zámeru P. Macha písat inak, ako je u vedeckých kníh zvykom, a to trochu žurnalisticky, sa text číta ako jedno vel'ké detektívne dobrodružstvo. Neustále som bola zvedavá, ako sa hladanie pravdy autorom skončí, či vecnými konštatovaniami, alebo hypotézami, ktorým sa taktiež - vel’mi otvorene - P. Macho nebráni a priznáva sa $\mathrm{k}$ nim.

Autor v monografii vychádza z mnohých vlastných výskumov pramenného charakteru, ktoré publikoval už v niektorých predchádzajúcich štúdiách či v monografii Milan Rastislav Štefánik v hlavách a v srdciach. Fenomén národného hrdinu v historickej pamäti (2011). Okrem archiválií z archívov rôznych typov (hlavne na Slovensku a v Prahe), ako sú úradné listiny, súdne rozhodnutia, materiály o dedičskom konaní, súkromné listy Štefánikovej rodiny, rukopisné verzie atd'. či dobová tlač, však oprel základné historické fakty o živote M. R. Štefánika aj o výsledky výskumov popredných slovenských historikov, ako sú Dušan Kováč, Mária Ferenčuhová, Ivan Kamenec, Michal Kšiňan atd'. Záver knihy tvorí fotografický materiál s popiskami, ktoré zároveň rekapitulujú niektoré dôležité udalosti v Štefánikovom živote. Nechýba ani bohatý zoznam prameňov a literatúry či menný index.

\section{prof. PhDr. Dagmar Inštitorisová, PhD.}

Katedra masmediálnej komunikácie a reklamy Filozofická fakulta, Univerzita Konštantína Filozofa
Dražovská 4, 94901 Nitra, Slovensko

dinstitorisova@ukf.sk 